\title{
KEEFEKTIVAN METODE LEARNING STARTS WITH A QUESTION PADA PEMBELAJARAN GEOMETRI
}

\author{
Lingga Nico Pradana \\ PGSD FIP IKIP PGRI Madiun \\ nicopgsd@ikippgrimadiun.ac.id
}

\begin{abstract}
This purpose of the research was to determine the effectiveness of learning start with a question methods on geometry learning. The effectiveness of these methods would be compared with presentation method. The method of this research was quasi experimental method with $2 x 1$ factorial design. The population of this study was the third semester students at PGSD IKIP PGRI MADIUN while the sample was $3 G$ as an experimental class and $3 C$ as the control class. The sampling technique used was cluster random sampling. Methods of data collection in this study was test method and divided into two: pre-test and post-test. Data analysis techniques used in this study is a t-test with two independent samples. The results of this study were learning starts with a question method was more effective than presentation method.
\end{abstract}

Keywords: method, learning start with a question, geometry learning

\section{PENDAHULUAN}

Geometri merupakan mata kuliah bidang keahlian dan keterampilan pada Program Studi Pendidikan Guru Sekolah Dasar (PGSD). Adapun materi yang dipelajari adalah geometri bidang dan ruang Euclides. Berisi tentang teorema-teorema Euclid dan penerapan dari teorema tersebut. Penerapan yang diberikan utamanya adalah bagian yang menunjang dalam pembelajaran geometri di Sekolah Dasar (SD).

Pembelajaran pada perkuliahan geometri, metode yang telah digunakan adalah presentasi. Siswa dibagi menjadi beberapa kelompok dan setiap kelompok diberikan materi untuk dipresentasikan di setiap pertemuan. Hal ini menimbulkan suatu permasalahan yang cukup signifikan. Permasalahan tersebut adalah kurang dikuasainya materi yang menimbulkan kesulitan dalam menyampaikan di depan kelas.
Hal tersebut juga berdampak pada pasifnya diskusi kelas karena baik penyaji ataupun penerima materi sama-sama tidak mampu menguasai materi dengan baik. Di sisi lain, pada geometri Euclid terdapat teorema-teorema yang harus dibuktikan agar penguasaan konsep dan penyesuaian materi terhadap aplikasi menjadi lebih baik. Oleh karena itu perlu dilakukan perbaikan pembelajaran pada perkuliahan geometri.

Berdasarkan hasil observasi yang telah dilakukan, kesulitan yang dialami siswa adalah kurangnya sumber-sumber materi yang mudah dipahami dan kurang bagusnya pemahaman siswa. Kesulitan tersebut secara langsung mempengaruhi proses pembelajaran sehingga nilai siswa menjadi tidak maksimal. Untuk mengatasi permasalahan tersebut, maka perlu dirancang suatu konsep pembelajaran yang mampu memudahkan siswa dalam memperoleh 
sumber belajar yang mudah dipahami. Selain itu perlu juga dibuat konsep pembelajaran yang dapat membuat siswa aktif dalam pembelajaran. Salah satu metode pembelajaran yang mampu membuat siswa aktif dalam pembelajaran adalah metode learning starts with a question. Metode tersebut membuat pembelajaran dimulai dengan bertanya. Pertanyaan-pertanyaan yang diajukan dapat jawab oleh guru maupun siswa yang lain. Di sisi lain, metode tanya jawab biasanya dilakukan dengan cara guru bertanya kepada siswa untuk memberikan stimulus demi membangun pengetahuan siswa. Penerapan metode tersebut justru akan memberatkan siswa karena pada dasarnya masalah yang dihadapi siswa adalah materi itu sendiri. Olson dan Knott (2013) mengatakan bahwa permasalahan dalam kelas bukan hanya dari pertanyaan guru tetapi bagaimana guru membentuk mindset siswa untuk berusaha menyelesaikan permasalahan. Dengan metode learning starts with a question guru dapat langsung mengetahui kesulitan siswa dalam memahami materi sehingga ada kemungkinan bahwa metode tersebut akan membuat pembelajaranmenjadi lebih efektif. Identifikasi tersebut juga dinyatakan Arnon (2009) dan Khalid et.al (2008) bahwa pertanyaan-pertanyaan yang diajukan dalam pembelajaran dapat membuat perkembangan pembelajaran menjadi lebih menarik. Oleh karena itu, metode tersebut dapat dijadikan bagian dari konsep pembelajaran dalam kelas.

Konsep pembelajaran yang dibuat dengan metode learning starts with a question adalah dengan membentuk kelompok belajar di dalam maupun luar kelas. Kelompok belajar di luar kelas dibentuk untuk berdiskusi sebelum pembelajaran di kelas dimulai sehingga pada tahap ini guru memfasilitasi siswa dengan materi dan pustaka-pustaka yang dibutuhkan oleh siswa. Di sisi lain, kelompok di dalam kelas dibentuk untuk melakukan diskusi perihal bagian materi yang masih belum dipahami sehingga pada tahap ini guru memfasilitasi siswa dalam berdiskusi. Menurut Jansen (2006) dalam penelitiannya, siswa lebih sukabekerja dalam kelompok untuk menyelesaikan suatu permasalahan di dalam kelas. Dengan konsep pembelajaran tersebut ada kemungkinan bahwa motivasi siswa dalam menyelesaikan permasalahan akan meningkat dan rasa ingin tahu siswa. Berdasarkan uraian tersebut maka tujuan penelitian ini adalah untuk mengetahui manakah yang lebih efektif antara pembelajaran dengan metode learning starts with a question dengan metode presentasi.

\section{METODE PENELITIAN}

Metode penelitian yang digunakan pada penelitian ini adalah metode quasi eksperiment. Metode tersebut digunakan karena keterbatasan peneliti yang tidak dapat mengontrol variabel luaran yang mempengaruhi penelitian. Populasi pada penelitian ini adalah seluruh siswa semester tiga IKIP PGRI Madiun. Teknik pengambilan sampel yang digunakan adalah cluster random sampling. Hasil pengambilan sampel yang telah dilakukan adalah kelas $3 \mathrm{G}$ sebagai kelas eksperimen dan kelas 3C sebagai kelas kontrol.

Teknik pengumpulan data yang dilakukan adalah metode tes yang terbagi menjadi dua bagian. Tes yang pertama dilakukan untuk mengambil data awal penelitian sebelum eksperimen yang digunakan untuk uji 
keseimbangan. Bentuk tes yang digunakan adalah soal subjektif dengan jumlah 8 soal. Uji yang dilakukan adalah uji validitas isi dengan tiga validator. Setelah itu dilakukan uji reliabilitas dengan formula Alpha. Tes yang kedua dilakukan untuk mengambil data setelah eksperimen dilakukan yang digunakan untuk menguji keefektifan metode pembelajaran. Tes dibuat dengan jumlah 8 soal. Instrumen tes tersebut sebelum digunakan akan diuji terlebih dahulu. Uji instrumen yang dilakukan adalah validitas isi dan reliabilitas.

Teknik analisis data yang digunakan pada penelitian ini adalah uji prasyarat, uji keseimbangan, dan uji hipotesis. Uji prasyarat yang digunakan adalah uji normalitas dengan metode Lilliefors dan uji homogenitas. Kemudian uji keseimbangan dan uji hipotesis di uji menggunakan uji t.

\section{HASIL PENELITIAN}

Penelitian diawali dengan mengadakan pre-test terhadap sampel penelitian. Data hasil pre-test digunakan untuk uji keseimbangan. Sebelum dilakukan uji keseimbangan, terlebih dahulu dilakukan uji prasyarat yaitu uji normalitas dan homogenitas. Hasil uji normalitas terdapat pada Tabel 1 .

Tabel 1. Rangkuman Uji Normalitas

\begin{tabular}{lcccc}
\hline Kelas & $L_{\text {obs }}$ & $L_{\text {tabel }}$ & $\begin{array}{c}\text { Keputusan } \\
\text { Uji }\end{array}$ & Kesimpulan \\
\hline Eksperimen & 0,11 & 0,14 & $H_{0}$ Diterima & $\begin{array}{c}\text { Berdistribusi } \\
\text { Normal }\end{array}$ \\
\hline Kontrol & 0,129 & 0,13 & $H_{0}$ Diterima & $\begin{array}{c}\text { Berdistribusi } \\
\text { Normal }\end{array}$ \\
\hline
\end{tabular}

Berdasarkan Tabel 1, maka terlihat bahwa nilai dari $L_{o b s}<L_{\text {tabel }}$. Hal tersebut berarti
$L_{\text {obs }} \notin D K \quad$ dengan $\quad D K=\{L \mid L>0,14\}$ sehingga baik pada kelas eksperimen maupun kontrol diperoleh bahwa sampel berasal dari populasi yang berdistribusi normal.

Tabel 2. Rangkuman Uji Homogenitas

\begin{tabular}{ccccc}
\hline Kelas & $F_{\text {obs }}$ & $F_{\text {tabel }}$ & $\begin{array}{c}\text { Keputu } \\
\text { san Uji }\end{array}$ & Kesimpulan \\
\hline $\begin{array}{c}\text { Eksperimen } \\
\text { dan } \\
\text { kontrol }\end{array}$ & 2,04 & 1,88 & $\begin{array}{c}H_{0} \\
\text { Ditolak }\end{array}$ & $\begin{array}{c}\text { Variansi } \\
\text { tidak } \\
\text { homogen }\end{array}$ \\
\hline
\end{tabular}

Berdasarkan Tabel 2, $F_{\text {obs }}<F_{\text {tabel }}$ sehingga $H_{0}$ ditolak. Oleh karena itu diperoleh kesimpulan bahwa variansi-variansi dari populasi tidak sama dan uji keseimbangan dilakukan dengan uji $t$ dengan $\sigma_{1}^{2} \neq \sigma_{2}^{2}$.

Berdasarkan hasil uji prasyarat pada Tabel 1 dan Tabel 2, maka persyaratan untuk melakukan uji keseimbangan telah dipenuhi. Uji keseimbangan dilakukan menggunakan uji t dua sampel. Hasil dari uji keseimbangan diperoleh nilai $t_{o b s}=1,675$ dengan daerah kritis $D K=\{t \mid t<-1,96$ atau $t>1,96\}$. Dari hasil tersebut maka $t_{o b s} \notin D K$ sehingga $\mathrm{H}_{0}$ diterima. Oleh karena itu diperoleh kesimpulan bahwa kemampuan siswa kelas eksperimen sama dengan kelas kontrol.

Setelah diketahui bahwa kedua kelas telah seimbang, maka proses eksperimen dilakukan selama 3 bulan. Kemudian dilakukan post-test untuk mengetahui data nilai pada pembelajaran geometri.Sebelum dilakukan uji hipotesis, terlebih dahulu dilakukan uji prasyarat dengan uji normalitas dan homogenitas. Hasil uji tersebut tersaji pada Tabel 3 dan Tabel 4 berikut. 
Tabel 3. Rangkuman Uji Normalitas Data Post-Test

\begin{tabular}{lcccc}
\hline \multicolumn{1}{c}{ Kelas } & $L_{\text {obs }}$ & $L_{\text {tabel }}$ & $\begin{array}{c}\text { Keputusan } \\
\text { Uji }\end{array}$ & $\begin{array}{c}\text { Kesim } \\
\text { pulan }\end{array}$ \\
\hline Eksperimen & 0,135 & 0,14 & $H_{0}$ Diterima & Normal \\
Kontrol & 0,112 & 0,136 & $H_{0}$ Diterima & Normal \\
\hline
\end{tabular}

Tabel 4. Rangkuman Uji Homogenitas

\begin{tabular}{lcccc}
\hline \multicolumn{1}{c}{ Kelas } & $F_{\text {obs }}$ & $F_{\text {tabel }}$ & $\begin{array}{c}\text { Keputusa } \\
\mathbf{n ~ U j i}\end{array}$ & $\begin{array}{c}\text { Kesimpul } \\
\text { an }\end{array}$ \\
\hline $\begin{array}{l}\text { Eksperimen } \\
\text { dan }\end{array}$ & 1,12 & 1,88 & $\begin{array}{c}H_{0} \\
\text { Domogen }\end{array}$ & Diterima \\
kontrol & & & & \\
\hline
\end{tabular}

Berdasarkan Tabel 3 dan Tabel4, maka baik pada kelas eksperimen dan kontrol dapat disimpulkan bahwa sampel berasal dari populasi yang berdistribusi normal. Pada uji homogenitas diperoleh bahwa variansi-variansi dari populasi sama. Oleh karena itu uji hipotesis akan dilakukan dengan uji $t$ dengan $\sigma_{1}^{2}=\sigma_{2}^{2}$.

Hasil dari uji hipotesis dengan uji tdiperoleh $t_{o b s}=2,591 \quad$ dengan $D K=\{t \mid t>1,645\}$. Dari hasil tersebut terlihat bahwa $t_{o b s} \in D K$ sehingga $\mathrm{H} 0$ ditolak. Karena H0 ditolak, maka kesimpulan dari pengujian hipotesis tersebut adalah pembelajaran metode learning starts with a question lebih efektif daripada metode presentasi.

\section{PEMBAHASAN}

Berdasarkan hasil pengujian hipotesis, diperoleh bahwa pembelajaran metode learning starts with a question lebih efektif daripada metode presentasi. Hal ini sesuai dengan hipotesis penelitian. Efek yang diberikan oleh metode learning starts with a question pada saat pembelajaran adalah siswa dapat mempelajari terlebih dahulu materi yang akan dibahas di kelas. Tiap-tiap materi dipelajari dalam kelompok belajar yang telah dibentuk dan setiap materi yang akan dibahas di kelas telah dipelajari sebelum oleh seluruh kelompok. Hal tersebut membuat siswa lebih siap dalam menjalani pembelajaran di dalam kelas. Kesiapan tersebut dimiliki oleh seluruh siswa pada .kelas eksperimen. Di sisi lain, siswa pada kelas kontrol dengan metode presentasi tidak memiliki kesiapan yang cukup. Materi yang diberikan kepada siswa tiap kelompok berbeda. Hal ini menyebabkan kesiapan yang dimiliki siswa dalam menghadapi pembelajaran hanya dimiliki oleh kelompok yang bertugas untuk presentasi. Pada saat pembelajaran dimulai terjadi banyak problem yaitu pemateri kurang menguasai konten materi yang dipresentasikan. Hal tersebut menyebabkan diskusi menjadi tidak berjalan dengan baik dan pembahasan materi kurang mendalam.

Pada proses pembelajaran dengan metode learning starts with a question, proses pembelajaran langsung dimulai dengan pengajuan pertanyaan oleh masing-masing kelompok. Pertanyaan tersebut merupakan pertanyaan tentang suatu hal yang belum atau sulit dipahami oleh siswa mengenai topik yang dibahas. Pertanyaan-pertanyaan yang diajukan lebih banyak dijawab oleh kelompok lain yang sudah paham terhadap permasalahan yang diajukan. Hal tersebut mengakibatkan terjadinya diskusi dalam kelas. Setiap kelompok dapat saling bertukar pengalaman belajar dan saling memberi solusi dari masalah yang ditemukan. Dengan proses pembelajaran tersebut, siswa dapat mengonstruk pengetahuannya sendiri berdasarkan 
pengalaman belajar dalam kelompok dan informasi dari kelompok yang lain. Barulah ketika diskusi selesai, guru memberikan penguatan dan evaluasi tentang topik yang dipelajari.Diskusi dari suatu pertanyaan akan memberikan pembahasan yang lebih bermakna. Pembahasan yang terjadi dalam kelas merupakan pembahasan yang merupakan permasalahan-permasalahan yang belum dikuasai siswa. Hal tersebut berarti proses diskusi dengan sumber pertanyaan tersebut dapat menjadi sarana saling melengkapi pengetahuan antar siswa. Dengan proses pembelajaran tersebut, maka proses konstruksi pengetahuan akan berlangsung dengan baik (Dori 1999, Ruitenberg 2009, Flynn 2012).

Iklim pembelajaran dengan metode learning start with a questiondalam kelas dapat memberikan kondisi seperti komunitas bertanya. Kondisi ini disebabkan karena keaktivan siswa dalam kelas yang memiliki rasa ingin tahu terhadap konten yang dipelajari. Peran guru di kelas yaitu sebagai moderator untuk menyambungkan pertanyaan siswa yang kemudian dijawab oleh siswa lain. Kemudian jika pembahasan menemui jalan buntu dalam artian terdapat pertanyaan yang tidak dapat dijawab maupun diselesaikan oleh siswa, maka guru dalam hal ini berfungsi sebagai narasumber dalam menjawab permasalahan tersebut. Sejalan dengan penelitian Wang \& Chua (2010) dan Fukumoto (2007) yang menjelaskan tentang komunitas bertanya pada kelas. Pembelajaran yang berbasis komunitas bertanya dalam kelas memiliki keefektifan yang lebih tinggi daripada pembelajaran tradisional. Selain itu dapat membuat siswa menjadi lebih kritis dan meningkatkan kemampuan bertanya dari siswa. Oleh karena itu pembelajaran akan lebih efisien jika menggunakan metode learning start with a question.

Berdasarkan proses pembelajaran dari metode learning starts with a question dan presentasi, hasil belajar siswa berbanding lurus dengan kefektifan kedua metode tersebut dalam pembelajaran.Siswa pada pembelajaran learning starts with a question memiliki nilainilai yang lebih tinggi daripada siswa pada pembelajaran presentasi.Hal ini ditunjukkan dengan nilai rata-rata siswa kelas eksperimen yaitu 71,05 dan kelas kontrol 63,21. Nilai ratarata dari kelas eksperimen memiliki perbedaan yang signifikan dengan nilai rata-rata kelas kontrol. Nilai tersebut juga menunjukkan hasil pembelajaran geometri oleh siswa yang mendapat metode learning starts with a question lebih baik daripada yang mendapat metode presentasi. Hal tersebut juga sejalan dengan teori pada penelitian Anne et.al (2007) dan Freeman et.al. (2014) pembelajaran aktif dalam artian pembelajaran yang mampu meningkatkan keaktivan siswa di kelas dapat meningkatkan performa siswa dalam kaitannya untuk menjawab suatu permasalahan. Selain itu pembelajaran aktif juga dapat meningkatkan hasil pembelajaran siswa dalam bidang matematika lebih khusus dalam hal ini adalah pembelajaran geometri.

\section{SIMPULAN DAN SARAN}

Berdasarkan hasil penelitian dan pembahasan maka kesimpulan dari penelitian ini adalah pembelajaran metode learning starts with a question lebih efektif daripada metode presentasi. Metode learning starts with a question tersebut mampu memberikan pembelajaran yang aktif sehingga hasil 
pembelajaran geometri menjadi lebih baik. Hasil belajar yang baik tersebut didukung dengan proses pembelajaran yang aktif dan bersifat konstruktivisme.

Mendasar pada hal tersebut maka peneliti menyarankan pada siswa untuk selalu aktif terutama dalam mengajukan pertanyaan berkaitan dengan substansi pembelajaran. Dosen sangat diharapkan untuk selalu menggunakan metode-metode pembelajaran aktif seperti metode learning start with a question untuk membelajarkan siswadengan baik. Bagi peneliti lain sebaiknya selalu meneliti dan mengkaji tentang metode-metode pembelajaran aktif sehingga dapat ditawarkan dengan bukti empiris kepada guru maupun dosen untuk membelajarkan siswa.

\section{DAFTAR PUSTAKA}

Anne, H., Shelli, B., \& Edward, W. 2007. Active Learning and Technology: Designing Change for Faculty, Students, and Institutions. EDUCAUSE Review. Vol. 42. No. 5. p.42-44.

Arnon, S., Reichel, N. 2009. Closed and Open-Ended Question Tools in a Telephone Survey About "The Good Teacher" An Example of a Mixed Method Study. Journal of Mixed Methods Research. Vol. 3. No. 2.p. 172-196.

Dori, Y., Herscovitz, O. 1999. Question-Posing Capability as an Alternative Evaluation Method: Analysis od an Environmental Case Study. Journal of Research In Science Teaching. Vol. 36. No. 4. p. 411-430.

Flynn, A. 2012. Development of an Online, Postclass Question Method and Its Integration with Teaching Strategies. Journal of Chemical Education. Vol. 89. No.4. p. 456-464.

Fukumoto, J. 2007. Question Answering System for Non-factoid Type Questions and Automatic Evaluation based on BE Method. In Proc. NTCIR-6Workshop Meeting. p. 441-447.

Freeman, R., Eddy, S., McDonough, M., Smith, M., Okoroafor, N., Jordt, H., \& Wenderoth, M. 2014. Active Learning Increases Student Performance in Science, Engineering, and Mathematics. PNAS. Vol. 111. No. 23. p. 8410-8415.

Jansen, A. 2006. Seventh Graders' Motivations for Participating in Two Discussion-Oriented MathematicsClassrooms. The Elementary School Journal. Vol. 106. No. 5. p. 409-427.

Khalid, M., Jijkoun, V., Rijke, M. 2008. The Impact of Named Entity Normalization on Information Retrieval for Question Answering. Lecture Notes in Computer Science. Vol. 4956. p. 705-710. 
Olson, J., Knott, L. 2012. When a problem is more than a teacher's question. Education Study Mathematic. Vol. 83. No. 2. p. 27-36.

Ruitenberg, C. 2009. Introduction: The Question of Method in Philosophy of Education. Journal of Philosophy of Education. Vol. 43. Issue 3. p. 315-323.

Wang, K., \& Chua, T. 2010. Exploiting Salient Patterns for Question Detection and Question Retrieval in Community-based Question Answering. In Proc. International Conference on Computational Linguistics. p. 1155-1163. 